\title{
DO SUJEITO À PRESENÇA COMO TRANSITIVIDADE PARA O SER: O DESAFIO DE UMA PASSAGEM EPOCAL SOB A ÓTICA DO PENSAMENTO DE HEIDEGGER
}

\author{
From Subject to Presence as Transitivity to Being: \\ The Challenge of a Epochal Passage under the Optical of the Thoughts of Heidegger. \\ Del Sujeto a la Presencia en Cuanto Transitividad para el Ser: \\ El Reto de un Pasaje Epocal en la Optica del Pensamiento de Heidegger
}

Marcos AurÉLIo Fernandes

\begin{abstract}
Resumo: O presente texto parte da situação do homem na contemporaneidade. Trata-se da situação de uma passagem crítica. Crise, porém, é risco e oportunidade. O risco está na desolação decorrente do esquecimento do Ser. A oportunidade (kairós) está no apelo do porvir que atinge o homem, isto é, o apelo de fundar uma abertura, um espaço-de-liberdade, que deixa ser o Ser. É a oportunidade de uma transformação radical do homem: de sujeito, senhor do ente, caracterizado pela sua autonomia ou vontade-para-o-poder, para a presença (Dasein), em que o homem encontra a sua humanidade sendo o pastor (cuidador) do Ser. O artigo caminha abrindo uma via de reflexão percorrendo com Heidegger essa passagem do sujeito para a presença; depois, tematiza o sentido ontológico da existência, enquanto liberdade, enquanto exposição ao ente na totalidade e insistência na abertura do Ser. Por fim, busca evidenciar o cuidado, dinâmica fundamental da existência, como transitividade, ou seja, como fundação do "aí": da abertura do ente como tal e no seu todo.
\end{abstract}

Palavras-chave: sujeito, presença, existência, liberdade, cuidado, ente, Ser.

\begin{abstract}
The present text arises from the contemporaneity of man's situation. It deals with the situation of a critical transition. Crisis, however, is a risk and an opportunity. The risk is in the desolation arising from the forgottenness of being. The opportunity (kairós) is in the appeal of the future which touches man, that is, the appeal to establish an openness, a space for liberty, that let be being as such. It is an opportunity for a radical transformation of man: From subject, master of being, characterized by his autonomy or will to power, to presence (Dasein), in which man encounter his humanity as shepherd (caretaker) of being as such. The article moves on, opening a way of reflection, traversing with Heidegger this passage from subject to presence; afterwards, thematise the ontological sense of existence as liberty or exposure to being in its totality and insistence to openness to being as such. Finally, it seeks to point out the care, the fundamental dynamic of existence, as transitivity, or as the foundation of the "there": from the openness of being as such and in its totality.

Keywords: subject; presence; existence; liberty; care; being; being as such.

Resumen: El presente texto parte de la situación del hombre en la sociedad contemporánea. Es la situación de un pasaje crítico. Crisis, sin embargo, es un riesgo y una oportunidad. El riesgo está en la desolación resultante del olvido del Ser. La oportunidad (kairós) se encuentra en apelación del futuro que llega al hombre, es decir, la apelación de fundar una apertura, un espacio de libertad, que deja ser el ser. Es la oportunidad para una transformación radical del hombre: de sujeto, señor del ente, que se caracteriza por su autonomía o la voluntad de la potencia, para presencia (Dasein), en la cual el hombre encuentra su humanidad siendo el pastor (cuidador) del ser como tal. El artículo intenta la apertura de una vía de reflexión al caminar con Heidegger en este pasaje del sujeto para la presencia. A continuación, explica el sentido ontológico de la existencia en cuanto libertad, o en cuanto exposición al ente en su totalidad y la insistencia en la apertura del Ser. Por último, busca evidenciar el cuidado, dinámica fundamental de la existencia, en cuanto transitividad, i. e., en cuanto fundación del "ahí": de la apertura del ente en cuanto tal y en su conjunto.

Palabras-clave: sujeto; presencia; existencia; libertad; cuidado; ente; ser.
\end{abstract}

\section{Os Passes e os Impasses de uma Passagem}

Hoje vivemos uma época de crise, por conseguinte, uma época de decisão, entre riscos e oportunidades. A história parece ter mergulhado profundamente naquilo que o poeta Hölderlin denominou de "noite do mundo" (Heidegger, 1946/1994a, p. 269). Nesta noite, poetas e pen- sadores se tornam sentinelas. A sentinela é alguém que vigia, ou seja, que se mantém desperto e vigilante, à espera do dia. Esta noite já fora pressentida no fim do século XIX por Nietzsche. Este, no contexto da crise epocal, que se instalava sub-repticiamente enquanto a civilização europeia celebrava as glórias do progresso, viu a grandeza do humano em ser uma passagem e um ocaso. "O que é 
grande no homem é isto, que ele é uma ponte e não um fim; o que pode ser amado no homem é isto, que ele é uma passagem e um ocaso" (Nietzsche, 1883-1885/1994, p. 12). A tarefa que incumbe o homem, em meio a esta crise epocal, é de se ultrapassar a si mesmo, de ir além do homem que existiu até agora. Por isso, para Nietzsche, o homem em sua essência de futuro é o homem da passagem (Übergang). Mas esse homem da passagem, de uma passagem que conduz para além do homem que existiu até agora, é também o homem do ocaso (Untergang): o homem que declina. Entretanto, essa vicissitude do declínio é, justamente, o que nos incumbe de cumprir uma passagem, de ir além do homem que existiu até agora.

A crise é risco, mas é também oportunidade. Novo kairós, novo tempo oportuno. Tempo, segundo Nietzsche, de o "espírito leão", que diz "não" e que quer ser senhor e deus de tudo, característico do homem moderno, se transformar em "espírito criança".

A criança é a inocência, é o esquecer, um novo início, um brincar, uma roda que rola a partir de si, um primeiro movimento originário, uma santa afirmação. Sim, para o jogo da criação, meus irmãos, é necessário um sagrado "dizer-sim": a sua vontade quer pois o espírito, o seu mundo conquista para si aquele que perdeu o mundo (Nietzsche, 1883-1885/1994, p. 26).

Hoje, experimentamos os passes e os impasses dessa passagem, que tem se tornado uma passagem por um hiato da história. Os passes, nós celebramos nas conquistas estupendas que o mundo da objetividade e da funcionalidade nos presenteia. Mas, aí mesmo, nós experimentamos os impasses. Os impasses aparecem nas contradições desse nosso mundo dito pós-moderno. O triunfo da racionalidade científica e tecnológica, a sociedade da informação e do conhecimento, não significa conquista do saber e da sabedoria. A passagem que está em questão nessa crise, precisa, pois, ser uma ultrapassagem dos passes e impasses do mundo contemporâneo. Trata-se de uma ultrapassagem que passa "no nada", no vazio e hiato de dois mundos. Nessa ultrapassagem, trata-se de esboçar, de imaginar, um novo homem, um novo modo de ser humano, que já não seja mais o homem da objetividade e da funcionalidade e nem o seu correlato, o homem da subjetividade moderna. A imaginação desse homem se esboça em Ser e Tempo sob o nome de Dasein, "presença".

\section{O Acontecer de uma Transformação Radical do Humano: Da Subjetividade à Presença}

O homem é sempre um projeto. Melhor: ele é o poema apenas começado do ser, conforme a sentença poético-pensante: "Nós chegamos tarde para os deuses e muito cedo para o ser. Deste, poema começado é o homem" (Heidegger, 1954/2000, p. 48). É que ao homem não é dado ser homem fora da situação de um kairós. Kairós significa, em Hesíodo, "o apropriado", a "medida do que convém", daí, o "decisivo". Kairós, diz, pois, o tempo da decisão, o tempo da cisão, do abrir-se de uma fenda, de um hiato, em que se inaugura uma oportunidade. É o tempo propício, que traz, no seu bojo, o perigo, e, junto com o perigo, a proximidade favorável do que salva, conforme o dito cantante de Hölderlin, evocado por Heidegger, ao situar o lugar da questão da técnica: "ora, onde mora o perigo / é lá que também cresce / o que salva” (Heidegger, 1953/2001, p. 31). Como podemos ver em nosso tempo a abrir-se de um hiato? Como este hiato inaugura uma oportunidade, com seus perigos e suas chances?

No nosso tempo, o humano sofre uma transformação radical. Nós somos cidadãos de dois mundos: um velho que se esvai e um novo que ainda não se delineou claramente. No intervalo entre estes dois mundos, nós experimentamos, neste início do terceiro milênio e do século XXI, o destino de termos de ser homens da passagem, à espera da irrupção, em nós e nas gerações posteriores, de outro modo de ser homem, um modo que seja digno de ser considerado próprio do "homem humano".

Vivemos um tempo em que a aceleração das transformações da figura do ser-homem parece chegar ao paroxismo. Transformam-se, hoje, as próprias estruturas do ser-homem. As transformações destas estruturas produzem fraturas históricas, fraturas que são expostas nas movimentações inquietas do homem contemporâneo. Essa inquietude é compreensível, pois o homem, hoje, vive no vazio de um hiato: velhos padrões de vida se desvanecem e novos parâmetros de viver ainda não emergem. Chegamos ao ocaso de um dia histórico de dois milênios e meio e um novo dia histórico ainda não surgiu. Nesse hiato, nesta pausa, nesta noite, é grande o perigo. Não são poucos os alarmes que soam hoje, alertando para o perigo da destruição ambiental que está em curso. Na realidade, vivemos hoje não somente o perigo de que o homem se destrua a si mesmo e ao que existe de vivente na terra. Vivemos também no risco de que o homem continue a existir, sem, contudo, se tornar o homem humano que ele pode ser, sem encontrar a sua própria humanidade e sem resguardá-la, em si e nos outros, e em todos os seus relacionamentos. "O grande desafio de nossa época é o desafio de uma conversão do homem para a sua jovialidade. Impõe-se uma conversão que reponha o homem no lugar de sua humanidade, na sua essência de futuro" (Leão, 1989, p. 42).

É a partir desse desafio que em Ser e Tempo pensou-se a essência de futuro do homem como Dasein, como presença. Trata-se de um modo de ser que ultrapassa o modo de ser da funcionalidade, isto é, da objetividade e da subjetividade, predominantes na modernidade. $\mathrm{Na}$ modernidade, o homem continua sendo o "animal racional" da tradição ocidental. Mas, com um diferencial: o vivente (animal) homem está posto para si mesmo e diante do mundo na condição de "sujeito". O "sujeito" é 
o fundamento, o substrato a partir donde se dá, graças à racionalidade, a constituição do mundo, como uma totalidade de sentido, que encerra toda uma gama de significados, isto é, de valores, elaborados social e historicamente. O homem vige como responsável por si mesmo e pelo mundo que ele constitui a partir do conhecimento. Na condição de sujeito, o homem está posto diante da interpelação de ter que, sempre de novo, se responsabilizar por si e por tudo. Nietzsche experimentou esta interpelação como vontade-para-o-poder (Wille zur Macht). Ao animal (vivente) racional da autonomia não basta querer isto ou aquilo. Ele precisa querer o querer do próprio querer, numa contínua busca de poder, isto é, de potência, de conservação e potencialização de suas possibilidades de viver. Entretanto, o vivente racional e passional que assim quer e se quer, em sua autonomia, esquece-se que ele não é o fundamento mesmo deste querer. O homem moderno celebra a autonomia como um feito da sua liberdade. Mas a liberdade mesma, não está em poder do homem. O homem não escolhe ser livre. A liberdade não lhe pertence. É o homem que pertence à liberdade. A liberdade lhe é dada, com o próprio dom de ser o que ele é. O que ele é, porém, o homem precisa vir a ser, precisa tornar-se. Por isso, ao homem não basta ser homem, ele tem que ser humano, tem que chegar, num porvir e devir, a ser o que ele é. Mas essa humanidade (essência humana) ele só pode encontrar à medida que se recorda de que o ser que lhe é dado como tarefa também lhe é dado como dom; o ser que ele busca com o seu empenho, já lhe foi dado como penhor.

A essência da subjetividade está no seu caráter de poder. O "eu penso" é, no fundo, "eu posso". O máximo da expressão desse "eu posso" é a autonomia da liberdade. Autonomia é o poder-ser por meio do qual o eu se ergue a si mesmo, se alça e se realça no mundo. Mas, no fundo desse poder está um não-poder. Isso quer dizer: o "eu posso” é, na sua raiz, impotente, pois, já está desde sempre e para sempre submisso à necessidade da liberdade. Essa impossibilidade radical do "eu posso", porém, é a sua mais originária possibilidade. Trata-se, pois, de uma possibilidade impossível, se pensada a partir do eu, a qual se revela, se pensada a partir dela mesma, como impossibilidade possível, ou seja, possibilitadora do próprio eu e de tudo quanto ele pode. Esse poder que outorga e concede ao homem o poder-ser é, chama-se, para Heidegger, "ser". O ser é o que deixa ser o homem em seu poder-se. Contudo, o homem da subjetividade, que é o mesmo homem da objetividade, costuma ser cego para o ser. Ele só tem olhos para o ente e para o ente como objeto ou para o ente que ele mesmo é como sujeito. O ser só lhe aparece, obliquamente, como o nada, como, por exemplo, na angústia e no ser-para-a-morte.

Pensar a essência de futuro do homem como presença é, justamente pensar o homem a partir do ser. Mas, o que quer dizer "presença”? Em alemão, a palavra usada por Heidegger é "Dasein”. Heidegger usa a palavra fran- cesa "présence" (presença), aludindo ao significado usual de Dasein (Heidegger, 1936-1938/1994b, p. 300). É neste sentido usual que dizemos que uma cadeira é à medida que ela está presente, está aí, vigorando numa presença. Na modernidade, o "ente" como "presente" passa a ser interpretado como o que é apresentado e representado por e para um sujeito, ou seja, por um ente que é fundamento ou suporte (subjectum) de toda apresentação e representação dada no conhecimento. Este ente que é o suporte de todo o ente representado objetivamente se chama sujeito. A subjetividade do sujeito é compreendida a partir de sua função objetivante. A vigência dessa subjetividade, sua essência, por sua vez, se dá como autopresença ou como presença de si a si mesmo ("mens", "ego cogito", "res cogitans" em Descartes).

Na modernidade, a presença por excelência passa a ser o sujeito e sua subjetividade, ou seja, esta substância que é autopresente e que se apresenta e representa todo o ente no projeto de domínio calculador de todo o ente, pela ciência e pela técnica. A partir daí todo o ente, objetivo (presente como o que é contraposto ao eu) ou subjetivo (autopresente), se equaciona no horizonte da funcionalidade do "poder", ou melhor, da inessência do poder, que agencia o domínio, que tudo domina, explora e controla. O ser do ente, ou seja, a presença do presente passa a ser compreendido no horizonte da funcionalidade, isto é, como Bestand: recurso, insumo, elemento de um processamento infinito de produção. Em tudo isso, porém, a presença é pensada a partir da compreensão do ser como ser simplesmente dado (Vorhandenheit), como mera ocorrência, como simples caso (Vorkommnis), isto é, na perspectiva da disponibilidade para a produção. A compreensão do ser se nivela, portanto, na impessoalidade funcional. O homem mesmo se torna um "que", um elemento, recurso, mesmo que fundamental, dentro da vigência desta funcionalidade técnico-científica, a serviço da produção.

Contudo, o que em torno de Ser e Tempo Heidegger tenta imaginar, projetar e pensar como presença é justamente um outro modo de ser, que transcende esse modo de ser da subjetividade e da objetividade, enfim, o modo de ser da funcionalidade. "Presença" (Dasein) nomeia justamente a apreensão e compreensão de um poder-ser do homem, do humano e de sua humanidade, que se subtrai ao horizonte da simples ocorrência, quer como substancialidade, quer como subjetividade e objetividade, quer ainda como recurso (disponível) para a funcionalidade produtiva.

Nesta perspectiva de futuro, a mera presença (Vorhandenheit), a ocorrência (Vorkommnis) no horizonte da realidade como efetividade e funcionalidade (Wirklichkeit) em sua bipolaridade objetivo-subjetiva, merece mais ser chamada de ausência (Wegsein, apousia) do que de presença (Dasein, ousia). É que a este homem frenético, arrebatado, endoidecido e apaixonado pela mobilização total do produzir e do dominar, encantado 
pelos dispositivos e pelas disponibilizações da operacionalidade funcional da técnica, em toda a parte e a todo o momento ocupado e preocupado com o ente, permanece velado, oculto, desconhecido, o mistério do ser. Ele, epocalmente, "não está nem aí" para o mistério de ser. Este fechamento e encobrimento que vigora como esquecimento; melhor, como esquecimento do esquecimento, só pode ter o ser como nada, só pode ter o pensar que medita o sentido do ser como frenesi, como delírio, loucura. Esta situação não é superada ali onde se condena a racionalidade com sua unilateralidade e se procura refúgio no irracional, nas "vivências" (Heidegger, 1936-1938/1994b, p. 131). Por isso, o pós-moderno e suas fugas para o "irracional" é ainda, neste sentido, um prolongamento do moderno, da ausência que se consuma na modernidade, portanto, não é propriamente uma passagem, mas uma aparência de passagem. Nesta perspectiva de futuro é que o Dasein, a presença, se apresenta como uma tentativa de passagem no "kairós" do pensamento contemporâneo, uma passagem que ultrapassa tanto a objetividade como a subjetividade, tanto o racional como o irracional, tanto o cálculo como as vivências.

Presença é um modo de ser, no qual o aí é, tomando-se o verbo ser, por assim dizer, como ativo-transitivo (Heidegger, 1936-1938/1994b, p. 296). Presença é ser-o-aí-para-o-ser; é, por assim dizer, fundar o aí para o ser, deixar e fazer viger o aí, a saber, o aí para o ser e do ser. Presença é "estar aí" para o mistério do ser: declaração de interesse no mistério do ser; interesse de se deixar pôr numa relação, onde os relacionados, a saber, homem e ser, se solicitam mutuamente. Pois a relação, aqui, não pode ser entendida num sentido formal-vazio, matemático, mas sim num sentido existencial, entendendo o existencial não como subjetivo, mas como ek-sistencial, isto é, como dinâmica hiante, dinâmica de abertura para o ser. A essência fundamental da relação, tomada em sentido ek-sistencial, é ser-aproximado-a e deixar-se-interessar-por, um ser interpelado e interpelar, um ser solicitado e solicitar, um responder e corresponder (Heidegger, 1964/1994c, p. 232). Presença (Dasein) é ser o aí, ou seja, a abertura que deixa ser o ser em seu aí, em sua proximidade. É o cuidado de fundar, num deixar ser, a abertura para que se dê a vigência suave, a ressonância e a claridade do ser. É ser a "aberta”, a "clareira” (Lichtung) do ser. O homem, fundado na presença, deixa de ser o senhor do ente, para se tornar o pastor (cuidador) do ser (Heidegger, 1946/1949, p. 29). Somente cuidando do ser é que o homem deixa ser o ente como ente. Do contrário, no esquecimento do ser, o ente só vigora em sua inessência, em sua niilidade, está presente como se não estivesse presente, sem vigência, sua presença (ousia) é mais propriamente ausência (apousia).

A existência é o modo de ser da presença. Existência não é a subjetividade do sujeito. A existência vige como o dom e a tarefa de ser da presença. É respondendo à tarefa e correspondendo ao dom da existência que o homem se constitui como ser humano. Existência é o acontecer da liberdade. Existir significa: assumir a responsabilidade de ser. O ser que o homem é está entregue à sua responsabilidade. O ser se concede ao homem como um apelo, uma interpelação, como reivindicação de cuidado. Esta referência do ser ao homem expressa uma proximidade, uma intimidade de pertença, de apelo e ausculta. A presença é o aí do ser. Isto quer dizer: à presença o ser se doa como uma proximidade que interpela, ou melhor, que solicita uma resposta, uma correspondência. Presença é um modo de ser, que, em sua liberdade e responsabilidade, está aí para o ser. Ou seja: presença é o modo de ser que se interessa pelo ser, que se dispõe para a escuta de seu apelo, para a resposta à sua interpelação, para a correspondência à sua solicitação. Presença é o ente no qual o aí é. A tarefa de ser da presença consiste justamente em ser o aí do ser, ou seja, em estar aí para o ser. Isto significa: dizer-lhe, respondendo à sua chamada, "presente!". Na presença se revela, pois, um modo de ser no qual o homem se interessa pelo ser, a ele se dispõe, se abre, responde e corresponde. Ser presença, ser presente, significa, então: fundar o aí para o ser. Por sua vez, isto quer dizer: deixar ser o ser; deixá-lo viger como ser, ser na disposição de escutar e de corresponder ao seu apelo, ser na consonância, na concordância, no acordo (harmonia) com o ser, abrir-lhe uma clareira, em que ele possa se aproximar, advir e sobrevir, viger e perdurar, em que possa repercutir o seu toque, ressoar a sua fala silenciosa, difundir-se a sua claridade. Com outras palavras, ser presença é cuidar do ser.

Hoje nós conhecemos o homem como o senhor do ente. Assim sendo, desconhecemos o modo de ser da presença. Neste sentido, o que caracteriza o modo de ser dominante do homem hoje é antes a ausência do que a presença. A grande questão que toca ao homem hoje é se ele será capaz de fazer uma passagem, a saber, a passagem da ausência (Wegsein, apousia) para a presença (Dasein, ousia). Passar da ausência para a presença quer dizer: deixar de ser o senhor do ente para ser o cuidador do ser. Deixar de apenas calcular e dominar, mandar, desmandar e comandar o ente, para pensar (denken), isto é, agradecer (danken), acolher e celebrar a dádiva de ser, para responder e corresponder ao seu apelo silencioso que chama o homem para ser o que ele é e para cuidar do Todo.

\section{Presença como Existência: Poder-Ser e Liberdade}

Presença não nomeia um "que" (Was), mas um "quem" (Wer) (Heidegger, 1927/1986, p. 45). Isto quer dizer: a pergunta que está em jogo, aí, não é: "o que é o homem?”; mas: "quem é o homem?". É que seu ser não é ocorrência de uma coisa, seja como coisa simplesmente dada (Vorhandenheit), seja como coisa à mão, dada no manejo do uso (Zuhandenheit), antes, o seu ser é, vige como, existência (Existenz). 
No §9 de Ser e Tempo (Heidegger, 1927/1986, p. 42) anuncia-se a existência como "essência" da presença: "Das "Wesen” des Daseins liegt in seiner Existenz" - "A 'essência' da presença jaz em sua existência”. Os caracteres deste ente não são "propriedades” simplesmente dadas de um ente simplesmente dado, mas são para ele, cada vez, possíveis modos de ser (mögliche Weisen zu sein). 0 que pode ser dito da presença, mais do que características reais de um ente real, no sentido de uma coisa simplesmente dada ou à mão, são modos possíveis de ser, são possibilidades. O humano do homem, o humano no homem, não é realidade, mas possibilidade. Por isso, não é dado, caso ou fato, mas tarefa, quefazer, afazer de liberdade. Aqui, por sua vez, possibilidade não se diz no sentido do possível abstrato, mas no sentido do possível concreto, ou seja, do poder-ser que se mostra como poder-ser somente na concreção do empenho ativo, afetivo e efetivo, ou seja, o poder-ser como capacidade de ser. O mesmo texto diz também: "Alles Sosein dieses Seienden ist primär sein" - "Todo ser-assim deste ente é primordialmente ser". Ente, aqui, há de ser entendido como "sendo", ou seja, em sentido verbal, mais que nominal: como particípio (em grego e latim) ou como gerúndio (em português). Somos. Isto quer dizer: estamos sendo, participando, tomando parte no ser, sendo gerados no ser. Também ser, aqui, há de ser entendido em sentido verbal. Há ser, dá-se ser. O seu dar-se se expressa como verbo, antes de tudo. "Ente” nomeia tudo quanto há ou pode haver, tudo quanto é, todo o "sendo". E o sendo que somos se caracteriza por ser uma relação de ser com o ser, relação esta que se dá como disposição, compreensão e linguagem (conforme os §§29 a 34 de Ser e Tempo: Heidegger, 1927/1986, p. 124-166). Por isso, todo "ser-assim” (Sosein) deste sendo é, primordialmente (primär) ser; o que implica: toda "característica” deste sendo há de ser entendida não nominalmente, mas verbalmente, não onticamente, mas ontologicamente, não categorialmente, mas existencialmente, não como "propriedade" de um ente, mas como possibilidade de ser, ou melhor, como poder-ser em referência ao ser.

É que o ôntico da presença é ontológico. Seu sendo se dá numa compreensão do ser, compreensão que é, fundamentalmente, sempre e cada vez um poder-ser (Seinkönnen); "poder" no sentido de "ser capaz de". Compreender é poder-ser, é ser capaz de... De que? Em última instância, ser capaz de ser. Mais determinadamente: ser capaz de ser livre. Ser livre, liberdade, aqui, não no sentido do mero livre-arbítrio tomado como "liberdade da indiferença” (libertas indifferentiae). De fato, esta liberdade permanece abstrata, uma mera representação. Já a liberdade concreta do homem só acontece no exercício corpo-a-corpo da libertação, em que está em jogo o esforço por vir a ser o que ele é. De fato, toda escolha já é sempre feita, toda decisão já é sempre tomada, a partir de situações concretas, a partir também de disposições e predisposições em que o homem já se encontra em si mesmo, ou seja, a partir de possibilidades de ser que lhe são entregues e que lhe reclamam sua responsabilização, a modo de uma necessidade. Aqui, também não se há de entender somente como ser livre, liberdade, no sentido negativo da independência, como ser livre disso ou daquilo, desvencilhar-se disso ou daquilo. Mas há de se entender ser livre acima de tudo no sentido positivo de ser livre para, no sentido de compromisso, de comprometimento com o comprometimento, responsabilidade de ser. Isto quer dizer: ser livre não para isso ou para aquilo, mas, antes, ser livre para ser, quer dizer, para ser o que somos, ou seja, para ser existência, ek-sistência, abertura para o ser. Ser livre para ser propriamente existência, para ser existência em sentido próprio. "Das Dasein ist die Möglichkeit des Freiseins für das eigenste Seinkönnen" - "A presença é a possibilidade do ser-livre para o mais próprio poder-ser” (Heidegger, 1927/1986, p. 144. Grifo no original). A respeito da possibilidade como poder-ser, no $§ 9$ pode-se ler:

O sendo, ao qual, em seu ser, está em jogo este mesmo ser, se relaciona com o seu ser como sua mais própria possibilidade. Presença é, cada vez, sua possibilidade e ela a "tem" não só, ainda, a modo de propriedade, enquanto um sendo simplesmente dado. E porque presença é, essencialmente, cada vez, sua possibilidade, pode este sendo, em seu ser, "escolher" a si mesmo, pode se perder, respectivamente, pode nunca se ganhar ou se ganhar apenas "aparentemente" (Heidegger, 1927/1986, p. 421).

O humano no homem vige como um ente (um "sendo") que se atém ao ser, numa abertura. É o que diz, primordial e mais propriamente, a palavra "existência", em Ser e Tempo. Existência, e o que pertence à existência, é sempre de alguma maneira poder-ser, no sentido da concreção de um empenho: é esforço, labuta, luta, "tentação", embate, combate. Daí, o sentido "ativo" do ser da presença. Existir é empenho de combater, de combater o bom combate, em que está em jogo, nada mais nada menos do que o ser, ou seja, a nossa aptidão para ser, nas concreções fáticas em que nos encontramos a nós mesmos. É neste sentido que, na mesma passagem de Ser e Tempo, pode-se ler: “Das 'Wesen' dieses Seienden liegt in seinem Zu-sein” - "A 'essência' deste ente jaz em seu ter-que-ser” (Heidegger, 1927/1986, p. 42. Grifo no original). Mas, o que significa este "ter-que-ser" (Zu-sein)?

Talvez pudéssemos dizer assim: o ser que somos está sempre em aberto, sempre por se determinar, por se definir, por se finitizar, por se consumar, a partir de sua liberdade. Por ter que morrer um dia, o homem tem que morrer todo o dia. Por ter nascido um dia, o homem tem que nascer todo o dia. A cada vez, a cada nova situação, o homem tem que nascer e morrer. A cada vez, ele tem que

\footnotetext{
Tradução livre, grifo no original.
} 
irromper no aberto da sua liberdade (nascer, abrir-se) e se definir nos limites de sua responsabilidade (morrer, finitizar-se). Assim, para o homem, ser é, a cada vez, ter que ser, ter que se responsabilizar pelo que ele é e se torna e ter que se empenhar por vir a ser o melhor de seu próprio poder-ser. Por tudo isso, pode-se dizer que a existência vige como dom e tarefa de ser. É respondendo à tarefa e correspondendo ao dom da existência que o homem se constitui como ser humano, no sentido da presença. O que está, pois, em jogo, o que lhe importa sobremaneira é o seu próprio ser, que lhe está dado, mas dado não como fato ou caso acabado, mas sim como dádiva, a dádiva de uma tarefa por se fazer a partir da liberdade. Portanto, no existir em sua historicidade está em jogo, a cada vez, um ganhar-se e um perder-se, um não ganhar-se ou um ganhar-se apenas aparentemente.

Existir significa: assumir historicamente a responsabilidade de ser, na liberdade, comprometer-se com o mais próprio poder-ser, comprometimento com o comprometimento. O ser que o homem é lhe é transmitido (überantwortet: Heidegger, 1927/1986, p. 42). Existir em sentido próprio, portanto, é exercer a responsabilidade, a incumbência, de ser. Trata-se, por sua vez, de uma responsabilidade que não se incumbe apenas do "si mesmo" que a presença é para si mesma, mas que se incumbe do cuidado de tudo, de todo o sendo, do sendo na sua totalidade, do ser em todo e de todo o sendo.

\section{Existência como Exposição ao Ente e Insistência na Abertura do Ser. 0 Sentido Ontológico do Ser- -para-a-Morte}

Ser homem é, portanto, estar incumbido da responsabilidade de ser. O ser que somos nos é entregue como uma concessão e uma incumbência, que reclama nossa responsabilização. É-nos dado em aberto, por se fazer. É-nos dado como questão, como via e viagem de busca, de indagação, de investigação, que segue o dar-se e o retrair-se do sentido de ser.

Queiramos ou não, saibamos ou não, o que caracteriza a essência do homem é o doar-se ao dar-se do sentido do ser dos entes na sua totalidade. Tudo o que o homem faz e não faz, tudo que o homem pensa e não pensa, sente e não sente, sabe e não sabe, tudo que o homem é e não é atinge não somente a ele, mas sempre de novo os entes na sua totalidade, inclusive a ele mesmo, enquanto um ente dessa totalidade. A essência do homem está, pois, nisto: ele é responsável pelo seu ser e pelo ser dos entes na sua totalidade. O dar-se do sentido do ser dos entes na sua totalidade não se dá por si. É sempre obra do empenho de busca. De uma busca que se dá e se doa como via e história, como destino da existência (Harada, 2003, p. 180).
A busca por sentido é empenho e decisão do homem, mas é também dádiva do inesperado. Assim, essa busca, sempre de novo, se abre na espera do inesperado, na espera que, de repente, este sentido possa ser aprendido, ou melhor, possa ser apreendido, ainda que sub-repticiamente, ainda que se dando e se retirando como o clarão de um relâmpago. Esta responsabilidade, por conseguinte, incumbe o homem no seu todo, ou melhor, o homem no todo, o homem como ser-no-mundo, como configurador da totalidade significativa, viva e pulsante, chamada mundo, tomando essa palavra em sua acepção existencial, histórica. Na questão do sentido do ser o homem se responsabiliza pela totalidade em sua amplidão universal, em sua profundidade abissal e em sua originariedade inaugural. Ele se responsabiliza pela sua relação com tudo o que ele é e não é, com as coisas, com os outros, com o mundo e a terra, com os mortais e com o divino. Daí, o apelo inaugural, que nos foi transmitido por um dos sete sábios da Grécia antiga, Periandro, que

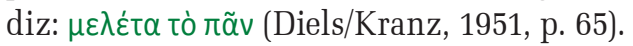

Ao homem, enquanto aquele ente que é solicitado para o cuidado do todo do ente, ou seja, o cuidado do sentido do ser, é dado o privilégio ontológico de existir, tomando-se esta palavra não no sentido de ocorrer, ser simplesmente dado, a modo de fato ou caso, mas na acepção de abertura (ek-sistir = expor-se, abrir-se, vir para fora e permanecer fora). No número 179 dos "Beiträge zur Philosophie", Contributos para a filosofia, (Heidegger, c. 1936-1938/1994b, p. 302-303), "existência” tem um sentido eminentemente temporal. Existência nomeia a plena temporalidade, ou seja, ela evoca e invoca um caráter extático: "ex-sistere" como ser e estar de pé (sistere) fora (ex). Como, pois, entender esse caráter extático da existência? Resposta: como exposição ao ente (Ausgesetztheit zum Seienden); ou melhor, como ser-inserido-em e estar-de-pé-fora na aberta do Ser (Eingerücktsein in und Hinausstehen in die Offenheit des Seyns). É a partir daí que se determina o "o quê" (Was), ou seja, o "quem" (Wer) da presença, quer dizer, a vigência do si-mesmo (die Selbstheit), aquilo que, de modo falho, nós chamamos de seu caráter "pessoal". É que o caráter "pessoal" da presença - o fato de que seu "quê" é um "quem" - se funda em sua responsabilidade de ser pelo ser que ela é e que ela não é, por todo o sendo em seu ser, isto é, pelo ser de todo o sendo e pelo modo como este ser se lhe ilumina. O seu ser-cada-vez-meu (Jemeinigkeit) se funda na responsabilidade de ser, no fato de a presença estar entregue à responsabilidade (überantwortet) pelo poder-ser mais próprio: "Jemeinigkeit meint Übereignetheit” - "Ser-cada-vez-meu quer dizer ser incumbido do próprio" (Cfr. Nota marginal que Heidegger escreveu em seu exemplar, à página 42 de Ser e Tempo - §9 - Heidegger, 1927/1986, p. 440). Por sua vez, é nesta responsabilidade pelo próprio e neste caráter de ser-cada-vez-meu que se fundam os modos de ser (Seinsmodi) da propriedade (Eigentlichkeit) e da impropriedade (Uneigentlichkeit) da presença (Heidegger, 1927/1986, p. 42-43). 
O mais próprio poder-ser, porém, se dá quando a presença assume a responsabilidade de ser em face da sua possibilidade extrema, que é a possibilidade da impossibilidade, ou seja, a morte. Existir, em sentido pleno e próprio, só pode quem "já morreu”. O que significa isto, aqui? "Morrer" não significa, aqui, findar, falecer. "Morrer" quer dizer, aqui, ser capaz de assumir a própria mortalidade, em vida. É encontrar e assumir a unidade dos opostos: vida-morte. Vida como desvelamento, morte como velamento. Não se trata, portanto, de uma antecipação do morrer como realidade, e sim de uma antecipação do morrer como possibilidade, como possibilidade da impossibilidade, possibilidade extrema, irremissível, insuperável, radical. Não se trata de tornar real a morte no morrer, mas de deixar-ser a possibilidade da morte, como possibilidade, ou seja, como poder-ser em que o próprio poder-ser, com sua responsabilidade de ser, com sua incumbência, é posto radicalmente em questão.

Em face da morte, a incumbência da responsabilidade de ser ressoa como a mais nítida e límpida reverberação da questão do ser, em sua radicalidade originária. Nessa ressonância o sentido do ser se dá e se retrai como a nitidez do nada. Nela, se desvela o velamento como velamento, vem à fala o mistério como mistério. É como um raio, que, num instante, faz visível o abismo do Nada. É quando a presença se nadifica, ou seja, se abre a si mesma no seu nada, no seu fundamento nulo, no abismo de sua niilidade. Viver e morrer deste modo a morte quer dizer, então, suportar a morte como a revelação do velamento, suportar a abertura prévia da existência em que se dão, ao mesmo tempo e como pertencentes um ao outro, o desvelado e o velado, a doação e o retraimento do mistério do ser.

Na morte todo e qualquer sentido determinado do ser entra em liquidação. Tudo o que somos e não somos, tudo que sabemos e não sabemos, tudo que fazemos e não fazemos, ontem, hoje, amanhã, toda a existência e o seu universo no tempo e no espaço está como que em suspensão, sem porquê, sem para quê, na nitidez do nada. Mas de tal sorte no nada que a própria compreensão usual do nada como negação ou ausência dos entes está suspensa. A morte é, pois, uma experiência da vida, consumada na própria existência, na qual a existência vem a si na sua radical e total possibilidade, vem a si na aguda percepção da responsabilidade pelo sentido do ser dos entes na sua totalidade, recolhida, alerta, toda precisão, toda ouvido ao vir e ao retrair-se do sentido do ser [...]. É a precisão, a afinação, o recolhimento, a nitidez dessa colhida, é o silêncio de alerta dessa audiência do sentido do ser que determina a tônica, a ressonância, a vitalidade, o 'humor' dos entes na sua totalidade, isto é, do mundo. É na medida da limpidez da audiência pelo sentido do ser que os entes, cada um em e por si e na sua totalidade vêm à sua identidade, aparecendo com a clareza de cada diferença, sem deformar os contornos, sem confundir níveis e dimensões (Harada, 1985, p. 203).

No n. 161 dos Contributos à Filosofia, a conexão entre morte e Ser vem à fala como a intenção originária do ser-para-a-morte (Sein zum Tode) de Ser e Tempo. A análise fenomenológica da morte, ali, só pode ser plenamente compreendida caso remeta para a questão do Ser (Seyn) a partir do horizonte do Tempo, ou seja, caso remeta à temporalidade e, no horizonte da temporalidade como constituição extática da existência, à referência entre presença (Dasein) e Ser (Seyn). Neste contexto, aliás, a morte não é tomada no sentido de negação do Ser, mas, pelo contrário, no sentido de a mais alta e extrema testemunha do Ser. O que está em questão, portanto, não é uma "visão de mundo" negativa e pessimista da vida, mas sim um questionamento fundamental ontológico, que acolhe no fenômeno da morte o aceno para o "Nada", ou seja, para o não-ente, para o Ser mesmo (Heidegger, c. 1936-1938/1994b, p. 284).

\section{O Cuidado da Presença como Transitividade, como Fundação do Aí para o Ser}

A analítica existencial de Ser e Tempo trouxe à luz o fenômeno do cuidado como constituição básica da existência. Em sendo no mundo, a presença pertence ao cuidado. O cuidado determina e sustenta o seu ser-no-mundo (é a lição do parágrafo 41 de Ser e Tempo: Heidegger, 1927/1986, p. 191-196). De fato, o ser-em, ou melhor, o em-ser (In-Sein) do ser-em-o-mundo, consiste, precisamente, no morar, no habitar, no demorar-se e deter-se junto a, junto ao mundo, enquanto o entorno inaugurado pelo cuidado, enquanto a tessitura significativa tecida pelo próprio cuidado, pelo exercício concreto da própria responsabilidade de ser. O mundo vigora, pois, como aquela abertura, aquela irrupção no ser, realizada pelo cuidado. É por isso que a língua latina chamava de mundus o "limpo”, isto é, o lugar aberto pelo habitar e cultivar humano e de imundus, o inóspito, o não-lugar, a não-morada. É sendo no mundo e pertencendo ao cuidado que o humano nasce e morre, trabalha e descansa, encontra êxito e fracasso em suas empreitadas, experimenta miséria e abundância, prazer e dor, alegria e tristeza, desgraça e bênção. É sendo no mundo e pertencendo ao cuidado que a existência se abre como o espaço-de-jogo da liberdade, que a presença se instala na familiaridade do $\mathrm{co}^{-}$ tidiano e é surpreendida pela estranheza do incomum. É sendo no mundo e pertencendo ao cuidado que a presença é enviada pelas vias da existência, experimentando, a cada passo, os lances do destino, as determinações da facticidade.

Desde o princípio e de antemão (vorweg), a existência surge como o lance de abertura e irrupção no medium 
(meio, no sentido de elemento) do ser, como lance prévio, projeto (Entwurf). Existência é envio, é destinação. É por isso que, sendo no mundo, a presença está sempre em vias de, e, nascendo e morrendo a cada vez, está sempre a caminho, se conduzindo, se dirigindo, se direcionando, e, a partir do cuidado, se responsabilizando pelo que ela é e pelo que ela não é. Por isso, a existência é projeto. Mas projeto não é programa. O programa se atém ao real, a possibilidades dadas, prontas, disponíveis. O projeto é criativo, é concreção da liberdade criativa que vigora na "raiz", na radicalidade originária, na origem mesma da existência. O projeto, com efeito, se atém a possibilidades por se criar, por se conquistar, por se realizar. Se o programa é sempre de alguma maneira um controle planificado e calculado do real, o projeto é espera do inesperado. Para o humano, ser um projeto significa, a partir da abertura do porvir, da convocação ou incumbência da responsabilidade de ser, de vir a ser o que ele é no sentido de seu poder-ser mais próprio, retomar o fato de já ser, atuando o próprio poder-ser no entremeio de uma tensão entre o já e o ainda-não. Assim, a existência é fenda e abertura, em que o homem encontra-se de antemão lançado, na tensão entre a superfície e a profundidade, o claro e o escuro, o descoberto e o encoberto, o sim e o não. Deste modo, o homem é desafiado a constituir a sua identidade por meio das diferenças e das diferenciações, dos opostos e das oposições, num contínuo diálogo consigo mesmo e com o outro. Assim sendo, o homem não nasce pronto. Por isso, a cada momento, ser humano significa estar no combate por e para ser, por e para ser o que se é. Toda essa incessante busca, que se torna, para o pensar, uma verdadeira questão, mostra a existência como um contínuo porfazer e um permanente perfazer-se, como uma obra da liberdade criativa do ser, da vida: um evento sem "para quê", um acontecimento da gratuidade da vida, que, em sua originariedade, vive sem "por quê", vive simplesmente por e para viver. Existir em sentido mais próprio é ser livre por e para esta liberdade criativa do ser, que nós costumamos chamar de vida (no sentido existencial, histórico). Presença é um modo de ser, que, em sua liberdade, isto é, em seu ser livre para a liberdade criativa, em sua responsabilidade de ser, está aí para o ser. Ou seja: presença é o modo de ser que se interessa pelo ser, que se dispõe para a escuta de seu apelo, para a resposta à sua interpelação, para a correspondência à sua solicitação. Presença é o sendo no qual o aí é, no qual a liberdade criativa do ser se torna próxima e, em sua proximidade, deixa vir para a proximidade todas as coisas, como em sua morada, como em seu "ethos".

A tarefa de ser da presença consiste justamente em ser o aí do ser, ou seja, em estar aí para o Ser. Presença é o acontecer da atitude de disposição e interesse pelo Ser. Dis-posição, no sentido de um pôr-se-na-abertura-para (dis-posição); e interesse, no sentido de um pôr-se-no-medium-ser (inter-esse). Numa tal disposição e interesse, a presença responde e corresponde ao apelo do ser, que solicita o cuidado. Isto significa que a presença diz ao Ser e ao seu apelo: "presente!". Na presença se revela, pois, um modo de ser no qual o homem se interessa pelo Ser, a ele se dispõe, se abre, responde e corresponde.

A partir da presença e do cuidado, o homem sofre uma transformação essencial. O ser-homem se compreende, agora, a partir da referência ao Ser enquanto Ser (Seyn), ou seja, ao Ser (Seyn) não enquanto entidade do ente (Sein = Seiendheit), mas ao Ser enquanto "Ereignis", ou seja, enquanto o acontecer que deixa a cada sendo (ente) ser o que ele propriamente é. Esta "referência" de ser ao ser acontece por muitos modos de cuidado: no modo do pensar (denkerisch), do poetizar (dichterisch), do construir (bauend), do guiar (führend), do ofertar (opfernd), do sofrer (leidend), do jubilar-se (jubeln) (Heidegger, c. 1936-1938/1994b, p. 302). Assim, o homem é chamado a cuidar do sentido do ser, ou melhor, a "guardar a Verdade do Ser", a aberta epocal que lhe está destinada, a livre abertura em que, numa determinada fulguração e configuração epocal, o ente se ilumina, e o Ser se dá num jogo de híbrido de retraimento e velamento, de luz e de sombra, de desencobrimento e encobrimento. Cuidar do sentido do ser, da "Verdade do Ser", quer pensando, quer poetizando, quer construindo, quer conduzindo, quer ofertando, quer sofrendo, quer jubilando-se é a incumbência ou vocação ontológica fundamental do homem humano. É o sentido da famosa passagem de "Sobre o Humanismo" em que o homem aparece na configuração do "pastor do Ser" (Heidegger, 1946/1949, p. 29).

Ser presença, ser presente, significa, então: fundar o aí para o ser. É o sentido literal da palavra "Da-sein", como se pode ler no n. 173 dos "Contributos para a Filosofia":

O Da-sein não é o modo de realidade de cada e todo ente, mas é ele mesmo o ser (Sein) do aí (Da). O aí, porém, é a abertura (Offenheit) do ente como tal no todo, o fundo (Grund) da originariamente pensada "aletheia". O Da-sein é um modo de ser, que, à medida que é (em sentido ativo-transitivo, por assim dizer) o aí, segundo este ser privilegiado e enquanto este ser mesmo, é um ente singular, único no seu gênero (o vigorar da vigência do Ser) (Heidegger, 1936-1938/1994b, p. 296²).

Entretanto, o que significa ser presença, ser em sentido ativo-transitivo o aí? "Ativo" remete a "ação" e "transitivo" a "passagem". O ser da presença está em ser ação e passagem que funda o aí, a abertura do sentido do ser, ou melhor, da Verdade do Ser. Com outras palavras, ser presença é deixar ser o Ser; deixá-lo viger na plenitude, na consumação de seu vigor, ser na disposição de escutar e de corresponder ao seu apelo, abrir-lhe uma clareira, em que ele possa se aproximar, advir e sobrevir, viger e perdurar, em que possa repercutir o seu toque, ressoar a sua fala silenciosa, difundir-se a sua claridade.

Grifo de Heidegger, tradução livre. 
Portanto, ser presença é cuidar do Ser. O que funda a existência é, pois, o cuidado com o Ser. A presença acontece propriamente em sua existência quando ela se liberta para ser quem ela é, ou seja, quando ela assume positivamente seu ser livre na disponibilidade para o Ser, quando se dispõe a vir a ser, a chegar a ser o que ela propriamente é e, assim, a cuidar do sentido do ser de tudo o que ela é e não é, a cuidar da Verdade do Ser, ou seja, a aberta ou clareira em que se dá, no jogo híbrido da liberdade, a claridade da luz e das sombras, do desvelado e do velado, do mundo e da terra, da terra e do céu, dos mortais e dos imortais, da familiaridade e da estranheza.

\section{Referências}

Diels, H. e Kranz, W. (1951). Die Fragmente der Vorsokratiker (Griechisch und Deutsch). Berlin: Weidmannsche Verlagsbuchhandlung.

Harada, H. (1985). A arte de humorizar a vida. Revista Grande Sinal (Petrópolis), 6, pp. 195-203.

Harada, H. (2003). Em comentando I Fioretti: reflexões franciscanas intempestivas. Bragança Paulista: EDUSF / Curitiba: Faculdade São Boaventura.

Heidegger, M. (1949). Über den Humanismus. Frankfurt am Main: Vittorio Klostermann (Original publicado em 1946).

Heidegger, M. (1986). Sein und Zeit. Tübingen: Max Niemeyer (Original publicado em 1927).
Heidegger, M. (1994a). Holzwege. Frankfurt am Main: Vittorio Klostermann (Original publicado em 1946).

Heidegger, M. (1994b). Beiträge zur Philosophie. Frankfurt am Main: Vittorio Klostermann (Original publicado em 1936-1938).

Heidegger, M. (1994c). Zollikoner Seminare. Frankfurt am Main: Vittorio Klostermann (Original publicado em 1964).

Heidegger, M. (2000). L'esperienza del pensare. Roma: Città Nuova (Original publicado em 1954).

Heidegger, M. (2001). Ensaios e conferências. Petrópolis-RJ: Vozes (Original publicado em 1953).

Leão, E. C. (1989). Aprendendo a pensar. Petrópolis: Vozes.

Nietzsche, F. (1994). Also Sprach Zarathustra: ein Buch für Alle und Keinen. Stuttgart: Reclam (Original publicado em 1883-1885).

Marcos Aurélio Fernandes - Graduado em Filosofia pela Universidade São Francisco, com Mestrado e Doutorado em Filosofia pela Pontifícia Universidade Antonianum. Atualmente é Professor do Departamento de Filosofia da Universidade de Brasília (UnB). Endereço Institucional: Campus Darcy Ribeiro, ICC norte, 70910-900. Email: framarcosaurelio@hotmail.com

Recebido em 16.09.12 Aceito em 18.07.13 